Sabina Pawlas-Czyż

(Uniwersytet Ślaski

Instytut Socjologii, Studium Pracy Socjalnej)

\title{
Społeczne konsekwencje choroby onkologicznej dla pacjenta i jego rodziny z perspektywy pracowników ośrodków hospicyjnych
}

\section{„Zakłócenie biograficzne” powodowane choroba onkologiczna $\mathbf{w}$ sferze relacji z otoczeniem społecznym}

Koncepcja choroby jako zakłócenia biograficznego Michela Bury'ego, oparta na koncepcji „sytuacji krytycznej” Anthony'ego Giddensa, choć sformułowana na podstawie wyników badań jakościowych, przeprowadzonych z osobami cierpiącymi na RZS, choć nie zyskuje w ten sposób znamion uniwersalności, stanowi teoretyczna bazę dla analiz konsekwencji doświadczenia również innych chorób, którym towarzyszy cierpienie fizyczne, ograniczenie, czy utrata sprawności. Koncepcja choroby jako zakłócenia biograficznego bywa zatem odnoszona w badaniach empirycznych do doświadczenia choroby nowotworowej - jednym z przykładów sa badania Sandi Cayless i jej współpracowników (Cayless i in. 2010:11-19 za Skrzypek 2011:199). Koncepcja Bury'ego została tu empirycznie zweryfikowana w obszarze choroby onkologicznej w badaniach, którymi objęto mężczyzn z diagnozą onkologiczną. Badano osoby zapadające w Wielkiej Brytanii na najczęstszą wśród mężczyzn postać raka - gruczołu krokowego. Doświadczenie choroby nowotworowej prowadzi - jak wykazano na podstawie badań - do zaburzenia codziennej struktury życia, do zaburzenia obrazu własnej osoby, własnej męskości, stanowiąc w sposób bardzo wyraźny zakłócenie biograficzne.

Zachorowanie na chorobę onkologiczna zmusza do doświadczenia stanów i rzeczywistości dotychczas nieznanych, odległych, dotyczacych do tej pory wyłącznie innych osób. Należą do nich: rozbicie dotychczasowych struktur życia, w tym także systemu wiedzy i przekonań, pojawia się konieczność doświadczania bólu i cierpienia, czasem śmierci. Zmianie ulec musi styl poznawczy, nastawienie wobec świata, a w miejsce 
dotychczasowych postaw musza ukształtować się nowe, osadzone w doświadczeniu choroby i cierpienia. Załamaniu ulegaja jawiące się jako oczywiste do tej pory zachowania, założenia, ale także głębsze systemy wiedzy, jak np. systemy objaśniajace. Osoba chora zmuszona jest do zmiany osobistej biografii, ale i indywidualnej koncepcji siebie.

Konsekwencje choroby przewlekłej rzutują również na obszar społecznych interakcji osoby chorej, w obrębie których poważnemu naruszeniu podlega zasada wzajemności w społecznych relacjach. Dominujacym doświadczeniem chorego staje się zależność (Bury 1982:169). Choroba wywiera w sposób oczywisty ogromny wpływ na ciało człowieka, a za jego pośrednictwem również na osobową tożsamość. Zmiany w obrębie ciała, jak pisze M.Bury, powoduja utrate zaufania do własnego ciała, a to prowadzi do spadku pewności siebie w kontaktach społecznych (Bury 1991:453). Jednostka w sposób nieuchronny doświadcza konieczności zmiany swego zaangażowania w szerszych relacjach osobistych i społecznych. Kluczowe znaczenie przypada istnieniu wspierającej sieci społecznej, która może znacząco różnicować przebieg ograniczania czy utraty sprawności w toku choroby.

Wspomniane aspekty koncepcji Michaela Bury'ego wybrane zostały dla zwrócenia uwagi na rozmiar konsekwencji doświadczenia choroby onkologicznej w obszarze społecznego funkcjonowania osoby chorej i znaczenia, jakie przypada relacjom $\mathrm{z}$ otoczeniem społecznym $\mathrm{z}$ perspektywy możliwości podtrzymywania dobrej jakości życia osoby chorej.

Zakłócenia w uczestnictwie w relacjach towarzyskich i życiu społecznym powstaja nie tylko w wyniku ograniczeń w funkcjonowaniu osoby, takich jak trudności z poruszaniem się czy problem zwiększonej męczliwości, ale także z powodu zakłopotania, jakie choroba generuje u innych. Nawet najprostsze wyjście $\mathrm{z}$ domu wymaga planowania na skalę ekspedycji, skutkując w rezultacie zawężaniem terenu własnej aktywności osób chorych do terytorium oswojonego, lokalnego, gdzie jednocześnie w mniejszym stopniu jest się narażonym na pełne pytań spojrzenia znajomych i obcych (Goffman 1968; Barker, Bury 1978 za: Bury 1982:175-176).

\section{Nieformalna opieka nad chorym onkologicznie członkiem rodziny - z perspektywy choroby jako trajektorii wedle Anselma Straussa}

Konfrontacja z choroba - szczególnie gdy mówimy o chorobie zagrażajacej życiu, czy o chorobie przewlekłej, swymi konsekwencjami dotyka nie tylko osobę chora. Staje się częścią doświadczenia całego systemu rodzinnego chorującej jednostki. A. Strauss i B. Glaser - znawcy 
problematyki socjologii choroby - w swej książce zatytułowanej „Chronic Illness and the Quality of Life" (1984), w centrum zainteresowan badawczych umieścili zagadnienie dotyczące możliwości prowadzenia przez ludzi chorych przewlekle względnie normalnego życia, pomimo tego, że jest to życie w obliczu choroby. Uwage przenieśli z badań skoncentrowanych wokół pacjentów i funkcjonowania instytucji medycznych na problematyke doświadczania choroby i radzenia sobie $\mathrm{z}$ nią $\mathrm{w}$ codziennym życiu.

Rozpatrujac zagadnienie radzenia sobie $\mathrm{z}$ chorobą przewlekła w kontekście prób prowadzenia normalnego, codziennego życia Anselm Strauss w projektach badawczych prowadzonych ze swoimi współpracownikami, szczególnie z Juliet Corbin, badał i opisywał różnorodne rodzaje pracy nad choroba, tzw. „pracy implikowanej choroba”. Prace ta, konieczną, by móc żyć względnie normalnie - jak wskazywali badacze - podejmuja zarówno chorujący, jak i członkowie ich rodzin. W ten sposób, w ramach socjologii medycyny wyraźnie zaznaczyło się podejście, zgodnie z którym, pojawienie się choroby oznacza konfrontację z nowymi trudnościami dla całej rodziny osoby chorujacej. W latach 80 ., w serii artykułów poświęconych problematyce choroby przewlekłej A. Strauss we współpracy z innymi badaczami wielokrotnie analizował te szczególne rodzaje pracy wykonywanej tak przez samych chorych jak i ich rodziny. To właśnie najbliższa rodzina - podkreślał Strauss - w ogromnej mierze zapewnia opiekę nad przewlekle chorymi osobami (Conrad, Bury 1997).

Radzenie sobie z choroba, w szczególności z choroba przewlekłą, przebiega nade wszystko w sferze domowo-rodzinnej, co wymaga wielu zmian w strukturze domu zorientowanego na „zarządzanie” choroba - czytamy w kluczowej dla tej problematyki książce „Unending Work and Care: Managing Chronic Illness at Home” A. Straussa i J. Corbin (Barr 1988). Potwierdzajac znaczenie rodziny w opiece nad osobą chora, uwage zwraca ogrom przygotowań i uzgodnień, jakie muszą być podjete, by prowadzić codzienne życie w obliczu choroby oraz jak delikatnych wewnatrzrodzinnych relacji to wymaga. Wiedza socjologiczna na temat życia z choroba przewlekła pogłębiona o zagadnienia dotyczące „problemów życiowych” oraz wyzwań „po powrocie do domu” w orientacji badawczej A. Straussa i B. Glasera pogłębia poznanie tego jak złożona jest aktywność wymagana w radzeniu sobie z choroba, właśnie w kontekście życia domowego przez osobę chora oraz jej rodzinę. Pozamedyczne konsekwencje życia z choroba, obejmujace konsekwencje społeczne i psychologiczne, to zmiany w strukturze życia, to codzienne trudności i ograniczenia dotyczące wielu obszarów problemowych. Wśród zadań, jakim podołać musza rodziny realizujace na co dzień opiekę nad jej chorym członkiem znajdują się: 
- zapobieganie kryzysom medycznym i radzenie sobie z nimi w przebiegu choroby;

- kontrolowanie objawów choroby;

- wdrażanie zaleconych reżimów terapeutycznych oraz radzenie sobie z wyłaniającymi sie w związku z tym problemami;

- zapobieganie społecznej izolacji i radzenie sobie z nia;

- przystosowanie do zmian w zakresie przebiegu choroby rozpatrywanego w kategoriach biomedycznych;

- działania nakierowane na normalizacje zarówno interakcji społecznych, jak i stylu życia;

- rozwiązywanie problemów finansowych, będących konsekwencja kosztów leczenia, a także całkowitej lub częściowej utraty pracy;

- radzenie sobie przez chorych z problemami psychologicznymi, małżeńskimi oraz rodzinnymi (Strauss i in. 1984:16 za Skrzypek 2011:147).

Radzenie sobie z tymi problemami życia codziennego wymaga opracowania pewnych „strategii podstawowych” (Strauss i in. 1984:18 za Skrzypek 2011:148), a ich efektywność zależna jest od odpowiedniej koordynacji działań podejmowanych przez osobę chora i jej rodzinę. Ważnym elementem jest przygotowanie rodzinne oraz organizacyjne, które zasadza się na posiadanych oraz dostępnych zasobach finansowych, medycznych i rodzinnych. Czynnikiem istotnie kształtujacym efektywność strategii podstawowych są też „umiejętności interakcyjne” oraz zaufanie pomiędzy osobami zaangażowanymi w pomaganie. Choroba wymaga pewnych szczególnych rodzajów pracy. Jest to praca nad chorobą, praca nad codziennością oraz praca nad biografią. Kategoria analityczna jaka jest pojęcie pracy w koncepcji choroby przewlekłej jako trajektorii zajmuje w niej miejsce szczególne. Rozumiane jest jako „zespół zadań realizowanych przez jednostkę lub małżeństwo, samodzielnie lub wspólnie $\mathrm{z}$ innymi, majacych na celu wykonanie planu działania ukierunkowanego na poradzenie sobie $\mathrm{z}$ jednym lub większa liczba aspektów choroby oraz życia osoby chorej i jej partnerów" (Corbin, Strauss 1985:9 za Skrzypek 2011:171).

Ta wykonywana praca nad chorobą odgrywa istotna rolę w kształtowaniu wzajemnych relacji pomiędzy wszystkimi zaangażowanymi osobami. Dostrzegalna jest zatem dwukierunkowość wzajemnych wpływów - z jednej strony praca nad chorobą dokonywana jest w ramach interakcji społecznych osoby chorej, wymaga by działania tu podejmowane przez wszystkie osoby były dobrze skoordynowane - z drugiej zaś strony interakcje społeczne kształtowane sa w procesie wykonywania pracy nad choroba.

Typologia trzech rodzajów pracy wykonywanej nad chorobą przez osobę chora oraz jej otoczenie powstała w wyniku badań - wywiadów 
z 60-cioma małżeństwami, w których pojawiły się takie choroby jak choroby nowotworowe, choroby serca, udar mózgu, porażenia dwu i czterokończynowe (Corbin, Strauss 1985: 225). Praca nad choroba w ujęciu J. Corbin i A. Straussa (illness related work) obejmuje te wszystkie działania, które zogniskowane są wokół objawów chorobowych, gdzie celem nadrzędnym staje się zapobieganie sytuacjom kryzysowym oraz pokonywanie ich w trakcie chorowania. Praca nad codziennościa (everyday life work) oznacza podejmowanie działań ukierunkowanych na wszelkie zadania, obowiązki, aktywności, jakie musza być realizowane, by utrzymać funkcjonowanie w poszczególnych sferach życia - zawodowej, domowej, rodzinnej. Zarówno praca nad choroba jak i praca nad codziennościa wpływa na charakter relacji ze wszystkimi osobami z otoczenia osoby chorej - współmałżonkami, dziećmi, rodzina, przyjaciółmi, specjalistami medycyny. W relacjach tych zachodza procesy wymiany informacji, sprawowania opieki, podziału obowiązków, ekspresji obaw. Praca nad biografią (biographical work) oznacza z kolei konieczność uwzględnienia w osobistej biografii osoby chorej doświadczenia choroby. Objawy choroby wymuszaja rekonstruowanie biografii, dokonywanie jej zmian podporzadkowanych ograniczeniom, stratom wynikających z choroby. Choć $\mathrm{z}$ cała pewnością choroba kształtuje, zmienia biografię, to również sama biografia - a szczególnie ważne wydarzenia biograficzne, jak np. ciąża - może rzutować na trajektorię choroby. Opisywane rodzaje pracy nad chorobą zwykle podejmowane być musza przez wszystkich zaangażowanych $\mathrm{w}$ chorobe $\mathrm{w}$ tym samym czasie. Zdaniem Straussa powoduje to zmniejszenie efektywności tych działań. Aby zatem praca nad choroba przynosiła wymierne rezultaty konieczne jest poczynienie specjalnych kroków przygotowawczych tak, aby możliwe było dobre skoordynowanie działań podejmowanych przez osoby z otoczenia chorego, uwzględniajace również właściwą organizację czasu. Co więcej, działania o charakterze uzgodnień musza być odnawiane, powtarzane wraz z każdym kolejnym etapem trajektorii chorowania. J. Corbin i A. Strauss zwracają również uwagę, że praca, jaka musi być wykonywana każdego dnia, może różnić się ilością zadań, stopniem ich trudności, wymaganym nakładem czasu czy konsekwencją, z jaką poszczególne działania muszą być realizowane. Zatem, radzenie sobie z chorobą w kontekście domowym oznacza nie tylko ogromną różnorodność w zakresie poszczególnych rodzajów pracy nad choroba, ale także w zakresie zróżnicowanych właściwości wymaganych działań (Corbin, Strauss 1985:226). Pojawiaja się sytuacje kryzysowe, ale i zadania rutynowe, jak np. poranne podawanie insuliny; niektóre zadania wymagaja ogromnej uwagi, dbałości o najmniejsze detale i pracy bardzo zajmującej, inne mogą być prostsze i nie wymagajace takich nakładów czasu i energii. 


\section{Potrzeby rodzinnych opiekunów osoby chorej onkologicznie - opieka jako wyzwanie biograficzne}

Koncepcja choroby jako zakłócenia biograficznego nie jest ograniczana swym zastosowaniem wyłącznie do osób chorych. Jak dowiedli P. Chamberlayne i A. King (Chamberlayne, King 1997) sprawowanie opieki nad osobą chora może pociagać za sobą szereg biograficznych konsekwencji, pozwalajacych rozpatrywać wyzwanie opieki w kategoriach zakłócenia biograficznego. Projekt zogniskowano wokół osób z otoczenia społecznego osób chorych, wokół ich perspektywy jako osób, które opiekujac się chorym, podobnie jak on musza wykonać prace związaną z uporaniem się z zakłóceniem biograficznym spowodowanym choroba. Zastosowane przez nich podejście biograficzne $\mathrm{w}$ badaniu konsekwencji choroby przewlekłej zwraca uwage na dwutorowość wpływów zakłócenia nią wywołanego. Obejmuja one z jednej strony praktyczne aspekty organizacji życia codziennego, z drugiej zaś wywieraja wpływ na koncepcje siebie oraz własną tożsamość. Stan wewnętrznej niepewności dotyczy nie tylko osób chorych, ale i ich opiekunów i jest ściśle powiązany z wattpliwościami dotyczącymi reakcji innych, jako że jednostka nigdy nie może być pewna czy jej sposób definiowania sytuacji będzie podzielany przez innych (Bury 1991:454, see also Riemann, Schuetze 1991:343 za Chamberlayne, King 1997:605-606). Jak wskazuje Rutman (1996:93 za Chamberlayne, King 1997:605) znalezienie sie w sytuacji sprawowania opieki najczęściej nie jest stanem oczekiwanym, pożądanym, podobnie jak charakter, intensywność opieki, w jaka osoba się angażuje nie daje się w łatwy sposób kontrolować ani przewidzieć. Dodatkowo konieczność radzenia sobie z systemem biurokracji medycznej, instytucjonalnej stanowi często inny rodzaj doświadczenia, w którym również zawiera się znaczący poziom niepewności. Wreszcie, trzecie niespodziewane źródło wyzwań związanych z opieka pochodzi z faktu zostania wrzuconym, osadzonym w złożonych, długotrwałych relacjach rodzinnych, w sieci niejawnych presji związanych niejednokrotnie z konfliktowymi powinnościami i konfliktowymi emocjami. Konfrontacja ze sprawowaniem opieki, z utrata, czy ograniczeniem sprawności członka rodziny jest często równoznaczna z punktem zwrotnym we własnej biografii, które znacząco kształtuje życie opiekuna (Denzin 1989:23 za Chamberlayne, King 1997:605). Odpowiedź na wyzwania związane $\mathrm{z}$ opieka pociaga za soba proces subiektywnego i praktycznego przystosowania własnej biografii, obejmującego zarówno wewnętrzny jak i zewnętrzny aspekt. Życie wewnętrzne oznacza w tym kontekście osobiste, emocjonalne reakcje na chorobe, jej symptomy, na osobe potrzebujaca opieki wraz z relacjami i rolami w obrębie rodziny czy przyjaciół. Życie 
zewnętrzne oznacza świat zewnętrznych możliwości, wyborów i ograniczeń stawianych przez świadczenia opieki społecznej, szersze postawy społeczne, dyskurs dotyczacy opieki społecznej i niepełnej sprawności, reakcje ze strony otoczenia społecznego. W wielu przypadkach opieka przynosi wraz z sobą znaczaca zmianę w obrębie cech biografii danej osoby, w teorii własnego życia, która jest siła sterująca jej aktywnością i która ulega nieprzerwanym zmianom (Rosenthal 1991 za Chamberlayne, King 1997:605). Mimo przemęczenia, spadku zaufania, wzrastajacej zależności czy utraconych marzeń - jak piszą J. Corbin i A. Strauss - wiele badanych małżeństw nie zaprzestaje wzajemnego wspierania się. Tym, co pomaga w utrzymaniu wzajemnego zrozumienia jest podobny poziom i rodzaj wiedzy, informacji, dotyczacych nie tylko choroby, ale także potrzeb, życzeń, oczekiwań obu małżonków. Warunkiem koniecznym jest jednak otwarta komunikacja (Corbin, Strauss 1985:245).

\section{Opieka hospicyjna w przezwyciężaniu trudności rodzinnych opiekunów osoby onkologicznie chorej}

Choroba terminalna, umieranie i śmierć ściśle osadzone są w kontekście instytucji medycznych. Proces zmedykalizowania umierania, jako wyraz aktywnego podejścia do śmierci, opisywany w wielu analizach empirycznych, poddawany jest dyskusji publicznej. Konsekwencja stosowanych $\mathrm{w}$ ramach tego podejścia profesjonalnych działan medycznych, stosowanych zabiegów i sprzętów jest nierzadko tworzenie warunków odizolowujących osobę chora i w sposób wstrząsający zabierających możliwość godnego umierania. „Okrutny aktywizm prowadzi do samotnego cierpienia umierajacego i izolowania jego bliskich. Próba przezwyciężenia stechnicyzowanego aktywizmu jest opieka hospicyjna” (Ogryzko-Wiewiórowska 2002:114). Badania psychoonkologiczne potwierdzaja, że rodzinni opiekunowie osoby nieuleczalnie chorej stanowia grupe podwyższonego ryzyka rozwoju trudności psychicznych po stracie bliskiej osoby, jeśli umiera ona w szpitalu. U $21 \%$ opiekunów chorego, który umierał w szpitalu obserwowano symptomy zespołu PTSD (posttraumatic stress disorder - zespół stresu pourazowego). Kiedy śmierć członka rodziny następowała w domu lub w hospicjum stan psychiczny członków rodziny był dużo lepszy - objawy zespołu stresu pourazowego dotyczyły 4,4\% badanych (Wright $\mathrm{i}$ in. 2010:28).

Współcześnie jedna z naczelnych zasad kształtujacych standardy pomocy udzielanej w ramach opieki hospicyjnej jest przyczynianie się do kształtowania społeczności wrażliwych na potrzeby pojawiające się u pacjentów i ich rodzin, tak aby możliwe było osiagnięcie możliwie 
satysfakcjonującego poziomu życia oraz wysokiego, zadowalającego stopnia przygotowania do śmierci - umysłowego i duchowego (Ostrowska 2005). Dzięki wypracowywanej przez założycielkę współczesnego ruchu hospicyjnego - Cicely Sanders - koncepcji opieki nad osobami nieuleczalnie chorymi, wiadomym jest dzisiaj, że sytuacja osoby terminalnie chorej wymaga, by ze szczególną troska potraktować kwestię zapewnianego jej wsparcia psychicznego i przyjać, że „uzdrawianie” sytuacji osoby w obliczu choroby nieuleczalnej nade wszystko wiąże się z podnoszeniem jakości życia we wszystkich sferach jej funkcjonowania i wzmacnianiem bliskich relacji z najbliższym otoczeniem (Kacperczyk 2006:85).

Oddziaływania opieki hospicyjnej - niezależnie od formy jaka ona przyjmuje (mamy tu do czynienia ze zróżnicowana struktura organizacyjna: sa to zespoły domowej opieki hospicyjnej, hospicja stacjonarne, ośrodki opieki dziennej) - sprzyjaja podnoszeniu jakości życia rodzin przeżywających kryzys wywołany nieuleczalną chorobą osób bliskich za pośrednictwem podstawowych, najbardziej powszechnych zasad konstytuujących opiekę hospicyjną. Ich pozytywny wpływ na codzienne życie rodziny osoby chorej można rozpatrywać na kilku płaszczyznach. Z jednej strony stosowana w praktyce zasada określająca integracyjny charakter udzielanego wsparcia, obejmującego wszystkie wymiary funkcjonowania osoby chorej (od somatycznej, emocjonalnej, psychicznej, poprzez sferę duchowa i społeczną) oraz zasada nakazująca projektowanie pomocy respektującej podmiotowość i autonomię pacjenta - dostarczają rodzinie zapewnienia, że choremu stwarzane sa warunki wszechstronnej pomocy, uwzględniajace jego indywidualne potrzeby. Świadomość otoczenia bliskiej osoby profesjonalną opieką może stanowić ważny element w odbudowywaniu poczucia kontroli nad biegiem wydarzeń.

Z drugiej strony, zgodnie z zasadami opieki hospicyjnej „opieka nad rodzina jest integralna częścia opieki nad pacjentem i trwa zarówno przez cały czas jego choroby, jak i po śmierci” (Górecki 2010:215), co powoduje, że w przeciwieństwie do jakiejkolwiek instytucji medycznej sama rodzina, jak i jej poszczególni członkowie moga uzyskiwać realne, bezpośrednie wzmocnienie ze strony hospicjantów. Zatem rodzina chorego zyskuje świadomość możliwości otrzymania wielopłaszczyznowego wsparcia nie tylko w zakresie opieki nad chorym ale również pomocy dla całego systemu rodzinnego w przezwyciężaniu trudności generowanych przez chorobe.

Rozpatrując działalność hospicjów w kontekście realizowania celu podnoszenia jakości życia rodzinnych opiekunów osoby chorej, należy zwrócić uwagę na ich rolę w przeciwdziałaniu społecznemu wykluczeniu. Jedną z częstych konsekwencji postępującej choroby w rodzinie jest 
zawężanie świata społecznych relacji zarówno osoby chorej jak i jej najbliższego otoczenia. „Członkowie rodziny w obliczu sytuacji kryzysowej, jaka jest choroba nowotworowa, najczęściej zostają pozostawieni samym sobie. Skupiaja cała uwagę i czas na chorym, prawie cała swoją energię wewnętrzna spalaja w procesie wspierania w chorobie i leczeniu najbliższej osoby, a to z kolei ma niebagatelny wpływ na jakość ich życia" (Pietrzyk 2006:38). Rodzinni opiekunowie chorego często działaja pozbawieni społecznego wsparcia. Jak wynika z badań przeprowadzonych w USA, $63 \%$ opiekunów osoby chorej sprawowało opiekę samodzielnie, bez jakiegokolwiek wsparcia (Ryn i in. 2011).

Podmiotem wsparcia hospicyjnego stają się wszyscy zagrożeni społeczna izolacja z powodu choroby terminalnej - osoby chore oraz ich rodziny i bliscy. Pojawienie się hospicjantów w życiu osoby chorej i jej rodziny jest momentem rozszerzenia społecznego otoczenia, wzbogacenia sfery kontaktów z innymi ludźmi.

Pracownicy ośrodków hospicyjnych pytani w badaniach A. Kacperczyk (2006) o rodzaje strategii interakcyjnych, jakie podejmowane sa wobec rodzin osoby chorej, wskazuja, że każdorazowo o zakresie udzielanego wsparcia rozstrzygają indywidualne czynniki, określajace sytuację rodzinna. Jeśli chory posiada rodzinę, hospicjanci opisywali cztery podstawowe rodzaje warunków, w jakich przebiega dostarczane mu wsparcie. Pełna i zaangażowana w opiekę rodzina stwarza warunki do udzielania przez hospicjantów wspomagania, które ma na celu usprawnianie opieki dostarczanej choremu przez rodzinę, a zatem obejmuje udzielanie rodzinie wsparcia informacyjnego, instrumentalnego, szkolenie członków rodziny, czasem wsparcie materialne. Zakres zaangażowania hospicjantów w pomoc zarówno osobie chorej oraz rodzinie wzrasta, gdy rodzina mimo zaangażowania w proces opieki sama boryka sie z własnymi problemami. Trzecim opisywanym na podstawie doświadczeń hospicyjnych kontekstem udzielania wsparcia jest sytuacja rodzin o słabej organizacji, które ponadto doświadczają różnych problemów opieki - tu nierzadko pomocy wymaga cała rodzina, pomoc bywa też zorientowana na wspomaganie organizacji rodziny. Zdaniem części pracowników hospicyjnych, gdy rodzina nie podejmuje obowiązku opieki nad chorym, pojawia się zadanie nakłonienia, zmobilizowania do podjęcia opieki nad chorym członkiem rodziny (Kacperczyk 2006:274). Zdaniem hospicjantów niezależnie od opisywanych wyżej warunków i sytuacji rodzinnej, choroba chroniczna stanowi sytuacje, która w sposób jednoznaczny wymaga zorganizowanej pomocy. Choć z analizy wypowiedzi hospicjantów wynika, że rodzaj podejmowanych działań jest niemal nieograniczony i każdorazowo wyznaczany aktualnie rozpoznanymi potrzebami chorego i jego rodziny, to „pomoc z zewnattrz ma 
pomóc systemowi rodzinnemu przetrwać i przejść z godnością przez trudne chwile, zachowujac przy tym podstawowe funkcje" (Kacperczyk 2006:243). Działania, jakie opiekunowie podejmuja najczęściej oprócz działań o charakterze medycznym, związanym szczególnie z kontrola bólu, czy pielęgnacja chorych, to pomoc w organizowaniu normalnego życia rodziny. W wielu przypadkach obecność hospicjanta oznacza dla opiekującego możliwość pójścia spać po kolejnej nieprzespanej nocy, czy możliwość wyjścia na zewnątrz.

[...] chodzitam do takiego ma / malutkiego Mariuszka tam na oddziat. [...] raz $w$ tygodniu przychodziłam do niego (wzdycha). To też tam poznatam jaka jest pomoca taki człowiek, który przychodzi... bo rodzic może na chwile wyjść z tego boksu! Wyjść na zakupy. Albo odetchnać świeżym powietrzem ... [...] (K2:528-536 Kacperczyk 2006: 242).

Hospicjanci opisuja konkretne przypadki wsparcia w zorganizowaniu pomocy dzieciom w odrabianiu lekcji, pomocy w zorganizowaniu czasu dla nich, pomocy w robieniu zakupów, kupowaniu i podawaniu leków. Czynności pielęgnacyjne wobec osoby chorej, wykonywanie czynności higienicznych wskazywane sa przez hospicjantów jako te, które częstokroć wymagaja wsparcia dodatkowej osoby, w szczególności, gdy opiekujący się jest osobą słaba, chora. Pomoc hospicjantów ma szczególne znaczenie w sytuacjach krytycznych, w sytuacjach, gdy rodzina reaguje paniką i przerażeniem na objawy choroby. Dostarczanie wiedzy, pomoc w rzeczowej ocenie sytuacji przywraca rodzinie możliwość racjonalnego działania. Wreszcie dostępność hospicjanta pozwala, by w rodzinie polepszać wzajemne komunikowanie, szczególnie ważne w przywracaniu zablokowanej komunikacji w odniesieniu do przeżywanych problemów, potrzeb. Hospicjant może udrażniać, uelastyczniać tę komunikację, by rozmowy o sprawach priorytetowych dla pacjenta i jego rodziny nie były spychane na margines. Podsumowując, udział hospicjantów w pomocy rodzinie chorego dotyczy nade wszystko normalizowania sytuacji całego systemu rodzinnego poprzez pomoc $\mathrm{w}$ organizowaniu codzienności, pomoc w opiece i towarzyszeniu choremu, zapewnianie pomocy stosownej do pojawiajacych się potrzeb oraz dostarczanie pewności o stałej obecności dostępnego źródła wsparcia (Kacperczyk 2006:244).

Analiza najczęstszych oczekiwań osób chorych oraz ich rodzin, jakie kierowane sa do hospicjów i hospicjantów, przeprowadzona przez Mirosława Góreckiego, wskazuje na trzy podstawowe grupy trudności, których rozwiązanie, dzięki pomocy hospicyjnej jest niezwykle istotne z perspektywy omawianej na łamach artykułu jakości życia członków rodziny osoby chorej. Wśród nich wymieniane są potrzeby związane z pomoca medyczna, ukierunkowaną na opanowanie sytuacji chronicznego, 
skrajnie nasilonego i trudnego do uśmierzenia bólu fizycznego osoby chorej. Jak pisze: „(...) „Sytuację okresu przejściowego” charakteryzuja przeto trzy dramatyczne okoliczności: ciagle powtarzajace się wołanie o pomoc, bezradność, brak będącego w pogotowiu układu wsparcia. Konsekwencja tego jest upokarzajace dla chorego stałe manifestowanie reakcji na ból i bezskuteczne dopraszanie się o ulgę, a ze strony bezsilnych opiekunów dezorientacja i poczucie winy. Toteż „okres przejściowy”, który wedle wszelkich zaleceń powinien przebiegać w klimacie spokoju i zapewnienia choremu komfortu psychicznego, w rzeczywistości staje sie koszmarem rozpaczliwej szamotaniny" (Górecki 2010:213). Konieczność obserwowania cierpienia bliskiej osoby jest jednym z najbardziej obciażających psychicznie doświadczeń. Każde działanie minimalizujące ból chorego przekłada się na samopoczucie członków rodziny.

Powodem poszukiwania przez rodziny wsparcia ze strony hospicjum jest zatem również pragnienie zapewnienia chorej osobie stałej opieki - szczególnie w tych okolicznościach, gdy opieka całodobowa jest koniecznością wynikająca $\mathrm{z}$ rodzaju objawów chorobowych, potrzeby nieprzerwanego monitorowania stanu pacjenta lub gdy rodzina nie może jej sprawować $\mathrm{w}$ związku $\mathrm{z}$ obciążeniami zawodowymi, czy ze względu na własny stan zdrowia np. zespół wyczerpania opieką. Trzecim z najczęściej zgłaszanych motywów poszukiwania wsparcia hospicjantów jest troska rodziny o zapewnienie choremu kontaktów podtrzymujacych, wspierających go psychicznie, emocjonalnie, wynikajaca ze świadomości znaczenia, jakie odgrywają satysfakcjonujace kontakty $\mathrm{z}$ innymi ludźmi.

Abstrahujac od codziennych sytuacji trudnych, które staja się udziałem rodziny skonfrontowanej z choroba nieuleczalną, czynnikiem, który w istotny sposób wpływa na jakość życia danego systemu rodzinnego jest to, jak radzi on sobie $\mathrm{z}$ kryzysem $\mathrm{w}$ wymiarze psychologicznym. Jak pisze Mariola Kosowicz, analizujac psychologiczne aspekty opieki nad umierajacymi oraz ich rodzinami to właśnie sposób radzenia sobie z kryzysem odsłania różnorodność problemów ujawnianych w wyniku prób przystosowania się systemu rodzinnego do zmienionej choroba sytuacji. Niektóre rodziny w obliczu choroby bliskiego zaczynaja przejawiać nadmierna sztywność, nadopiekuńczość ograniczająca autonomię osoby chorej. Inne, zaprzeczając chorobie moga swoimi reakcjami starać się zmuszać chorego do kontynuowania jego obowiązków i zadań realizowanych w rodzinie na dotychczasowym poziomie. Nierzadko spotkać można pojawiająca się $\mathrm{w}$ rodzinie skłonność do ucieczki, powodująca ograniczanie kontaktu z osobą chora, fizyczne izolowanie się od niej albo też na skutek własnych wewnętrznych lęków unikanie kontaktu psychicznego, otwartych rozmów oraz uczestniczenie w zmowie milczenia 
co do rzeczywistego stanu w jakim jest pacjent (Kosowicz 2010:277). Rodziny przejawiajace tego typu trudności, w kontakcie z opieka hospicyjna moga uzyskać psychologiczne wsparcie niezbędne w procesie rozszerzania świadomości po jakie zaradcze zachowania rodzina sięga w rzeczywistości, w jakim stopniu sa one dla niej korzystne oraz w poznaniu możliwych alternatywnych wzorów zachowania. Jakkolwiek to rodzina, jej wewnętrzna otwartość decyduja o wykorzystaniu dostępnego wsparcia, profesjonalnie przygotowany zespół jest nastawiony na identyfikację tych form pomocy, jakie rodzina jest w stanie przyjać.

Rozeznanie obszarów problemowych wpływających na jakość życia rodziny, przeprowadzone w badaniach autorstwa Agnieszki Pietrzyk, może stanowić baze dla sformułowania wskazań, jakie oddziaływania pomocowe hospicjów są szczególnie potrzebne rodzinie chorego. Obserwowane zmiany - jak pokazuja wyniki wspomnianych badań - dotycza większości analizowanych przez autorkę komponentów jakości życia, obejmujacych wymiar emocjonalny, komunikacje wewnattrz rodziny, relacje wewnętrzne i relacje $\mathrm{z}$ otoczeniem zewnętrznym, jak również wymiar zdrowotny oraz ekonomiczny w funkcjonowaniu rodziny. Zmianie ulega komunikacja wewnątrzrodzinna. Choć zauważalne są zmiany pozytywne: „wzmocnienie otwartości i szczerości rozmów, wyrażanie cierpliwości i wyrozumiałości” (Pietrzyk 2006:53), to widoczne sa i zmiany negatywne: „wprowadzenie barier komunikacyjnych, tematy tabu" (Pietrzyk 2006:53). Tematami najczęściej pomijanymi w rozmowach sa wedle obserwacji autorki te związane $\mathrm{z}$ choroba, rokowaniem leczenia, ale też z własnymi obawami, potrzebami, przy czym tematem najsilniej unikanym jest śmierć. Szczególnie często bariery komunikacyjne obserwowane sa u rodzin mocno ze sobą związanych emocjonalnie - bo tu pragnienie wzajemnego ochraniania i lęk przed cierpieniem był nasilony dużo mocniej. U części osób pojawiły się bóle głowy, zaburzenia pracy przewodu pokarmowego, zasłabnięcia i omdlenia. Wreszcie problemy bytowe i materialne niektórych rodzin narastały do stopnia, który prowadzić mógł do destabilizacji całego systemu rodzinnego. Zdarza się jednak, że nawet w skrajnie trudnej sytuacji ekonomicznej członkowie rodziny nie przyznaja tego, by chronić chorego przed poczuciem winy, czy obwinieniem go przez innych (Pietrzyk 2006:56-57). Jedna z cech charakterystycznych dla rodzin zmagajacych się z rakiem bliskiej osoby jest postępujacy proces ograniczania komunikacji wewnątrzrodzinnej. Głównym jej źródłem jest troska o zapewnienie choremu dobrego samopoczucia, chęć utrzymania możliwie spójnych relacji, nie wymagających angażowania dodatkowej energii, która zwykle jest w stanie wyczerpania nadmiarem codziennych problemów związanych $\mathrm{z}$ walka $\mathrm{z}$ choroba. Istnieje duże prawdopodobieństwo pojawienia się 
takich zjawisk jak: „negowanie konfliktu, tłumienie uczuć, racjonalizacja i unikanie agresji, złości i wrogości. W rodzinie zaczyna panować niepisana umowa nakazujacca unikanie wszelkich dodatkowych obciażeń. Rodzinna komunikacja ulega spłyceniu do prostych formuł: nie mówi się o osobistych emocjach, opiniach na temat choroby i jej leczenia, a tym bardziej możliwości umierania i śmierci osoby najbliższej, nie rozmawia się o nawarstwiających sie problemach materialnych” (Pietrzyk 2006:37).

Jedno z najtrudniejszych zadań, jakiemu musi stawić czoła rodzina osoby nieuleczalnie chorej dotyczy przekazywania informacji o terminalnym stanie i nadchodzacej śmierci. Wiele rodzin nie jest przygotowana do przeżywania i rozwiązywania związanych z tą decyzją dylematów moralnych. Jakkolwiek możliwości rodzin do przemyślanego i wyważonego działania są zróżnicowane, to nasilony lęk i dezorientacja często prowadzą do zwiększania barier komunikacyjnych i zamkniętego kontekstu świadomości (...). „często tak bywa, że pomiędzy chorym a rodziną wznosi się mur, czy raczej próżnia tworząca się wokół chorego, w części wytwarzana przez wystraszona rodzinę i zajęta głównie tym, by „nie dać poznać”. Potem osoby, które opiekowały się chorym maja wyrzuty sumienia, że nie zdobyły się wówczas na nawiązanie kontaktu z umierajacym (Górecki 2010:219).

To w znacznej mierze jednostkowe tendencje do ucieczki od tematu śmierci powoduja, że umieranie oznacza wykluczenie i samotność. Jak pisze Z. Bauman, nawiąując do wypowiedzi Norberta Eliasa „opis osobliwej nieporadności naszych słów i postaw w obliczu umierającego jest bezsprzecznie poprawny (...). Rzeczywiście nie wiemy, co powiedzieć umierajacym, choć z przyjemnością i łatwością rozmawialiśmy z nimi przedtem. Tak, czujemy się zakłopotani i aby pozbyć się poczucia zawstydzenia, wolelibyśmy w ogóle nie znaleźć się w obecności umierających, choć zanim zaczęli umierać, zachłannie poszukiwaliśmy ich towarzystwa i cieszyliśmy się każdą chwilą spędzaną razem" (Bauman 1998:155-156).

Wydaje się, że niepokój i niewiedza niektórych rodzin dotyczaca informowania chorego o jego stanie mogą być zmniejszone dzięki wsparciu hospicjantów. Choć nie ich rola jest nakłanianie rodziny do jakichkolwiek zachowań, to poprzez wyświetlenie argumentów za i przeciw mówieniu o faktycznym stanie, dostarczenie wiedzy o tym, jakie czynniki determinuja to czy informować chorego o rokowaniu, jak można uchronić chorego przed lękiem, przed negatywnymi konsekwencjami podania tej informacji moga stanowić efektywną pomoc w bardziej świadomym kierowaniu własnym zachowaniem i budowaniu większej bliskości zamiast oddalających relacji dystansu. 


\section{Zakończenie}

Znaczenie otoczenia społecznego dla skuteczności pracy nad choroba, w szczególności nad chorobą zagrażająca życiu jest kluczowe. Choć profesjonaliści medyczni zajmuja ważne miejsce $\mathrm{w}$ tym procesie, to stanowia jednak o części potrzebnych działań. Zdecydowana większość pozamedycznych zadań w opiece nad chorym realizowana jest w kontekście rodzinno-domowym. O skuteczności profesjonalistów medycznych, pracowników ośrodków pomocowych, w tym hospicyjnych przesadza fakt czy i na ile ich działania sa spójne, na ile dopełniaja pracę nad choroba jaka realizowana jest w obrebie rodzin. Kwestia rozstrzygajaca z perspektywy polityki zdrowotnej jest dopasowanie działań, jakie podejmują profesjonaliści medyczni do tych, jakie realizowane sa przez inne osoby profesjonalnie zajmujace się pomoca i z działaniami podejmowanymi w obrębie rodziny osoby chorej. Zdaje się, że nasza wiedza na temat stopnia skoordynowania tych wszystkich działań jest bardzo powierzchowna. Obszar ten jawi się jako ważny z punktu widzenia dokonywania uzgodnień, podnoszenia stopnia koordynacji działań. Jak bowiem piszą J. Corbin i A. Strauss (1985) ważna implikacja o charakterze praktycznym koncepcji choroby przewlekłej jako trajektorii jest wskazanie, by w praktyce medycznej działania podejmowane przez specjalistów medycyny aby wesprzeć osoby chore oraz ich rodziny były dostosowane do szczególnych cech danego etapu chorowania, a zatem i jednocześnie do repertuaru działań, jakie są w tej fazie podejmowane przez osoby ze społecznego kręgu chorego.

Nieformalna opieka na osoba chora w rodzinie oznacza uczestniczenie w nieprzerwanej pracy implikowanej choroba, która realizowana jest przez wszystkie osoby - z rodziny i spoza niej - które sa zaangażowane w relacji z chorym, które sa dotknięte skutkami chorowania. Ich aktywność ma na celu nie tylko przezwyciężanie wszystkich złożonych trudności generowanych przez chorobe, ale także dbanie o podtrzymywanie względnie normalnego życia na co dzień. Wysiłki osób podejmujacych pracę nad chorobą muszą być wzajemnie uzgadniane, a gdy nałożymy na to również siatkę potrzeb i problemów zmieniających się w poszczególnych fazach chorowania okaże się, że znajdowanie każdorazowo adekwatnych zasobów czasem finansowych, czasem medycznych, czasem społecznych może być zadaniem bardzo złożonym.

Zdaje się, że nasza wiedza pozostaje niepełna $\mathrm{w}$ odniesieniu do określenia tych aspektów życia rodzin opiekujących się osoba chora onkologicznie i tych aspektów życia codziennego, które pozostają pod szczególnym wpływem choroby i potrzebują uzgodnionego wsparcia ze strony profesjonalistów. Rozpoznanie zadań realizowanych w pracy nad chorobą, które rodzina w przypadku chorób nowotworowych jest 
w stanie podejmować samodzielnie, a które najczęściej wymagają pomocy ze strony otoczenia zewnętrznego to istotny element podnoszenia jakości życia całych rodzin i samych chorych. Istotne pytanie dotyczy również określenia obszarów, w obrębie których poprawa koordynacji działań instytucjonalnych i pozainstytucjonalnych miałaby szczególne znaczenie dla wszystkich zaangażowanych $\mathrm{w}$ proces pomocy.

\section{Bibliografia}

Barr J. (1988), Unending Work and Care: Managing Chronic Illness at Home by Juliet Corbin and Anselm Strauss, San Fransisco Jossey-Bass, Review, „Contemporary Sociology", vol. 18, no.6, s. 945-947.

Barker J., Bury M. (1978), Mobility and the elderly: a community challenge, [w:] V. Carver, P. Liddiard (eds), An Ageing Population, Hodder and Stoughton, Sevenoaks.

Bauman Z. (1998), Śmierć i nieśmiertelność. O wielości strategii życia, Wydawnictwo Naukowe PWN, Warszawa.

Bury M. (1982), Chronic Illness as Biographical Disruption, „Sociology of Health and Illness, 4, s. 167-182.

Bury M. (1991), The Sociology of Chronic Illness: A Review of Research and Prospects, „Sociology of Health and Illness”, 13, no. 4, s. 451-467.

Cayless S., Forbat L., Illingworth N., Hubbard G., KearneyK. (2010), Men with Prostate Cancer over the First Year of Illness: Their Experiences as Biographical Disruption, „Support Care Cancer”, 18, s. 11-19.

Chamberlayne P., King A. (1997), The biographical challenge of caring, „Sociology of Health and Illness", vol. 19, no. 5, s. 601-621.

Conrad P., Bury M. (1997), Anselm Strauss and the sociological study of chronic illness: a reflection and appreciation, „Sociology of Health and Illness”, vol. 19, no. 3, s. 373-376.

Corbin J.M., A. Strauss (1985), Managing Chronic Illness at Home: Three Lines of Work, "Qualitative Sociology”, vol. 8, no. 3, s. 224-247.

de Walden-Gałuszko K. (red.) (1994), Jakość życia w chorobie nowotworowej, Wydawnictwo Uniwersytetu Gdańskiego, Gdańsk.

Denzin N., (1989), Interpretive Biography, Sage, London.

Goffman E. (1968), Stigma: Notes of the Management of Spoiled Identity, Penguin Harmondsworth.

Górecki M. (2010), Przestanie ideowe i instytucjonalizacja wspomagania umierajacych, [w:] M. Górecki (red.), Prawda umierania i tajemnica śmierci, Wydawnictwo Akademickie Żak, Warszawa.

Kacperczyk A. (2006), Wsparcie społeczne w instytucjach opieki paliatywnej i hospicyjnej, Wydawnictwo Uniwersytetu Łódzkiego, Łódź.

Kosowicz M. (2010), Psychologiczne aspekty opieki nad umierajacymi i ich rodzinami, [w:] M. Górecki (red.), Prawda umierania i tajemnica śmierci, Wydawnictwo Akademickie Żak, Warszawa.

Ogryzko-Wiewiórowska M. (2002), Umieranie i śmierć. Perspektywa socjomedyczna, [w:] W. Piatkowski, A. Titkow (red.) W strone socjologii zdrowia, Wydawnictwo Uniwersytetu Marii Curie-Skłodowskiej, Lublin. 
Ostrowska A. (2005), Śmierć w doświadczeniu jednostki i społeczeństwa, Wydawnictwo IFiS PAN, Warszawa.

Pietrzyk A. (2006), Ta choroba $w$ rodzinie. Psycholog o raku, Oficyna Wydawnicza Impuls, Kraków.

Riemann G., Schuetze F. (1991), „Trajectory” as a basic theoretical concept for analysing suffering and disorderly social processes. [w:] D. Maines (eds), Social Organisation and Social Processes, New York.

Rosenthal G. (1991), German War memories: narrability and the biographical and social functions of remembering, „Oral History”, vol. 19, no. 2, s. 34-41.

Rutman D. (1996), Caregiving as women's work: women's experiences of powerfullness and powerlessness as caregivers, „Qualitative Health Research”, vol. 6, no. 1, s. $90-111$.

Skrzypek M. (2011), Perspektywa chorego w socjologii choroby przewlektej, Wydawnictwo KUL, Lublin.

Strauss A.L., Corbin J., Fagerhaugh S., Glaser B.G., Maines D., Suczek B., Wiener C.L. (1984), Chronic Illness and the Quality of life, second edition, The C.V. Mosty Company, St. Louis, Toronto.

van Ryn M., Sanders S., Kahn K., van Houtven C., Griffin J., Martin M., Atienza A., Phelan S., Finstad D., Rowland J. (2011), Objective burden, resources and other stressors among informal cancer caregivers: a hidden quality issue?, „Psycho-Oncology", 20, s. 44-52.

Wright AA., Keating Kl., Nalboni TA, Matulonis UA, Block SD, Prigerson HG (2010), Place of death: correlations with quality of life of patients with cancer and predictors of bereaved caregivers' mental health, „J Clin Oncol”, 28, s. 4457-4464.

\section{Social consequences of oncological disease for a patient and their family - hospice employees' perspective}

In research focused on the issue of increasing life quality of the oncologically ill patients the attention is paid to the need of extending it with research on life quality of families and caregivers directly looking after the patient. The close relationship of problems such as "the decreased quality of caregivers' life, and their difficulties with adaptation to the stress of serious condition of the close person inflict, among others, their relationships, quality of care and indirectly to the quality of the patient's life" (De Walden-Gałuszko 1994:33). This issue will be viewed from the perspective of the disease as a trajectory based on A. Strauss and J. Corbin. Their interactionist approach to the disease experience (showing the process of being ill in the categories of the actions taken by the ill person, their family and social environment) encourages to ask questions about factors that determine these particular types of actions a disease requires: managing the disease, day-to-day life and the biography. The above listed factors influence the character of the relationship with all the people from the ill person's environment - including health professionals - requiring good coordination and many arrangements at each stage of the disease. What role in this complex process can the employees of other support institutions play?

Key words: oncological disease, managing the disease, family caregivers of the ill person, hospice care. 